\title{
Upaya Meningkatkan Hasil Belajar Melalui Penggunaan Media Power Point pada Pembelajaran Tematik Siswa Kelas III
}

\author{
Nurhidayah \\ SD Negeri Kedawung 02 \\ nurhid89@gmail.com
}

\section{Article History}

accepted 01/11/2020

approved 08/11/2020

published 15/11/2020

\begin{abstract}
The purpose of this study is to improve student learning outcomes in thematic learning. This research is a classroom action research (PTK) which is carried out in three cycles, each cycle consisting of planning, implementing, observing, and reflecting stages. The subjects of this study were students of class III SD Negeri Kedawung 02, Kroya District, Cilacap Regency in the academic year 2020/2021, totaling 22 students. Data collection techniques using tests and observations. This study shows that the use of power point media can improve learning outcomes in thematic learning of class III SD Negeri Kedawung 02 in the 2020/2021 academic year as evidenced by the percentage of completeness of learning outcomes in cycle I of $77.3 \%$, cycle II of $90.1 \%$, and cycle III reaches $100 \%$.
\end{abstract}

Keywords: Learning Outcomes, Power Point, Students

\begin{abstract}
Abstrak
Tujuan penelitian ini adalah meningkatkan hasil belajar siswa pada pembelajaran tematik Penelitian ini merupakan Penelitian Tindakan kelas ( PTK ) yang dilaksanakan dalam tiga siklus, setiap siklus terdiri dari tahap perencanaan, pelaksanaan, observasi, dan refleksi. Subjek penelitian ini adalah siswa kelas III SD Negeri Kedawung 02 Kecamatan Kroya Kabupaten Cilacap tahun pelajaran 2020/2021 yang berjumlah 22 siswa. Teknik pengumpulan data menggunakan menggunakan tes dan observasi. Penelitian ini menunjukkan bahwa penggunaan media power point dapat meningkatkan hasil belajar pada pembelajaran tematik siswa kelas III SD Negeri Kedawung 02 tahun pelajaran 2020/2021 yang dibuktikan dengan presentase ketuntasan hasil belajar pada siklus I sebesar 77,3\%, siklus II sebesar 90,1\%, dan siklus III mencapai $100 \%$.
\end{abstract}

Kata kunci: Hasil Belajar, Power Point, Siswa

Social, Humanities, and Education Studies (SHEs): Conference Series https://jurnal.uns.ac.id/shes 


\section{PENDAHULUAN}

Keberhasilan proses pendidikan sangat bergantung pada praktisi pendidikan. Guru sebagai praktisi pendidikan yang berhadapan langsung dengan siswa harus mampu menciptakan suatu kondisi belajar yang kondusif. Guru dituntut untuk mampu mendistribusikan ilmu dengan baik dengan cara cara yang tepat disertai pembangunan karakter siswa agar memiliki kebripadian yang luhur. Di era modern dan serba teknologi ini, guru dituntut bersifat dinamis terhadap perkembangan teknologi yang berkembang pesat. Jika sistem pengajaran yang digunakan oleh para pengajar masih bersifat konvensional, maka dikhawatirkan para peserta didik sulit berkembang dan mengikuti perkembangan teknologi di masyarakat.

Berdasarkan pengamatan pada peserta didik di SD Negeri Kedawung 02 khususnya siswa kelas III, kegiatan pembelajaran sudah dilaksanakan secara maksimal. Akan tetapi siswa tampak masih kurang bersemangat dan kurang berminat terhadap pembelajaran. Hal ini terlihat dari sikap siswa ketika berada di dalam kelas. Banyak siswa terlihat diam tanpa merespon pembelajaran yang sedang berlangsung serta masih banyak siswa yang terlihat tidak fokus pada materi pembelajaran. Pada saat proses pembelajaran berlangsung banyak dijumpai siswa yang masih bicara sendiri. Hal ini dikarenakan dalam mengajar guru hanya menggunakan media konvensional yaitu berupa papan tulis, kapur, buku pegangan siswa, dan LKS. Guru masih mendominasi proses pembelajaran sedangkan siswa masih nampak pasif, guru dalam mengajar masih menggunakan metode ceramah dan kurang dalam memanfaatkan media pembelajaran.

Kurang efektifnya pembelajaran menggunakan metode ceramah serta minimnya media pembelajaran menyebabkan siswa bosan dan kurang berminat untuk mengikuti sehingga berdampak pada hasil belajar yang tidak maksimal. Hal ini terlihat dari nilai siswa yang masih rendah. Hal ini ditunjukkan dengan adanya siswa yang memperoleh nilai dibawah KKM (Kriteria Ketuntasan Minimal).

Menurut Oemar Hamalik (2001: 16), mengemukakan bahwa pemakaian media pengajaran dalam proses belajar mengajar dapat membangkitkan motivasi dan rangsangan kegiatan belajar, dan bahkan membawa pengaruh-pengaruh psikologis terhadap siswa. Penggunaan media pengajaran pada tahap orientasi pengajaran akan sangat membantu keefektifan proses pembelajaran dan penyampaian pesan isi pelajaran. Di samping itu, media pembelajaran juga dapat membantu peserta didik meningkatkan pemahaman, menyajikan data dengan menarik dan terpercaya, memudahkan penafsiran data, dan memadatkan informasi. Adapun media pembelajaran yang peneliti pilih adalah media powerpoint

Alamul Huda (2007:23) menyatakan bahwa Microsoft Powerpoint adalah salah satu bagian dari Microsoft Office yang ditujukan untuk membuat slide-slide presentasi yang menarik. Media powerpoint di setiap slidenya dapat menampilkan teks dan gambar bergerak dengan tata suara dan tata warna yang disesuaikan dengan penggunaannya sehingga dapat merangsang minat dan ketertarikan siswa terhadap suatu materi. Konsep pembelajaran yang dikemas dalam powerpoint dapat membantu siswa dalam memahami suatu konsep yang abstrak dan meningkatkan motivasi siswa serta membantu tercapainya tujuan suatu pembelajaran sehingga akan dapat meningkatkan prestasi siswa pula.

Berdasarkan latar belakang yang telah dipaparkan di atas, peneliti tertarik untuk melakukan penelitian dengan judul "Upaya Meningkatkan Hasil Belajar Melalui Penggunaan Media Power Point pada Pembelajaran Tematik Siswa Kelas III SD Negeri Kedawung 02". 
SHEs: Conference Series 3 (3) (2020) 341 - 346

\section{METODE}

Penelitian ini merupakan Penelitian Tindakan Kelas (PTK) yang dilaksanakan dalam tiga siklus. Setiap siklus terdiri dari tahap perencanaan, pelaksanaan, observasi, dan refleksi. Subjek penelitian ini adalah siswa kelas III SD Negeri Kedawung 02 tahun pelajaran 2020/2021 yang berjumlah 22 siswa. Data yang dianalisis berupa data kualitatif yaitu penggunaan media power point dan data kuantitatif yaitu hasil belajar siswa. Teknik pengumpulan data menggunakan tes dan observasi.

\section{HASIL DAN PEMBAHASAN}

Berdasarkan analisis hasil penelitian yang telah diuraikan, berikut penulis sampaikan pembahasan pada penelitian ini.

1. Penggunaan media power point

Hasil observasi penggunaan media power point adalah sebagai berikut:

Tabel 1. Hasil Observasi Penggunaan Media power Point

\begin{tabular}{lccc}
\hline \multicolumn{1}{c}{ Aspek } & \multicolumn{3}{c}{ Skor Rata-rata } \\
\hline & Siklus I & Siklus II & Siklus III \\
\hline Kesederhanaan & 4 & 5 & 5 \\
\hline Keterpaduan & 3 & 3 & 3 \\
\hline Penekanan & 2 & 3 & 4 \\
\hline Keseimbangan & 4 & 4 & 4 \\
\hline
\end{tabular}

Penggunaan media power point memiliki banyak kelebihan, Menurut Daryanto (2010: 164), powerpoint memiliki kelebihan sebagai berikut:

a. Penyajiannya menarik karena ada permainan warna, huruf, animasi, baik animasi teks maupun animasi gambar atau foto.

b. Lebih merangsang anak untuk mengetahui lebih jauh informasi tentang bahan ajar yang tersaji.

c. Pesan informasi secara visual akan mudah dipahami oleh siswa.

d. Guru tidak perlu banyak menerangkan bahan ajar yang sudah disajikan.

e. Dapat diperbanyak sesuai kebutuhan dan dapat dipakai secara berulang.

f. Dapat disimpan dalam bentuk data optik atau magnetik (CD, disket, flashdisk), sehingga praktis untuk dibawa kemana-mana.

Berdasarkan hasil observasi, penggunaan media power point yang peneliti terapkan sudah sejalan dengan beberapa poin yang disampaikan Daryanto. Penyajian yang menarik dapat merangsang motivasi siswa dalam kegiatan pembelajaran.

2. Hasil belajar siswa

Hasil penelitian menunjukkan peningkatan hasil belajar siswa pada materi kelas 3 tema 3 tentang benda di sekitarku. Peningkatan tersebut peneliti sajikan dalam tabel berikut.

Tabel 2. Peningkatan Hasil belajar Siswa

\begin{tabular}{clcccc}
\hline No & Nama Siswa & $\begin{array}{c}\text { Kondisi } \\
\text { Awal }\end{array}$ & Siklus I & Siklus II & Siklus III \\
\hline 1 & ALFANDRI M. & 48 & 56 & 85 & 85 \\
\hline 2 & ALYA NISA A. & 81 & 84 & 96 & 75 \\
\hline 3 & ASTRIT PUTRI A. & 79 & 88 & 90 & 95 \\
\hline 4 & A. NADA A & 75 & 84 & 84 & 95 \\
\hline 5 & B. BENZEMA P. P & 87 & 92 & 98 & 100 \\
\hline 6 & DEWI ANITA K. & 66 & 76 & 90 & 90 \\
\hline
\end{tabular}




\begin{tabular}{clcccc}
\hline 7 & DIMAS S. & 56 & 56 & 68 & 80 \\
\hline 8 & DUTA PUJI S. & 65 & 80 & 87 & 90 \\
\hline 9 & ELSINTA J. & 60 & 60 & 65 & 80 \\
\hline 10 & FAYI ARELIA H. & 94 & 96 & 100 & 95 \\
\hline 11 & FELIN AYU R. & 61 & 64 & 74 & 90 \\
\hline 12 & IQBAL A. & 65 & 72 & 89 & 90 \\
\hline 13 & JUWAN J. & 41 & 60 & 71 & 95 \\
\hline 14 & MUCH. ALFAT A. & 68 & 76 & 84 & 90 \\
\hline 15 & M. DLIAUL H. & 79 & 88 & 90 & 90 \\
\hline 16 & REFYIN DWI A. & 67 & 72 & 80 & 82 \\
\hline 17 & SILVIA ADYA M. & 73 & 80 & 85 & 85 \\
\hline 18 & TRI ADI L. & 73 & 76 & 81 & 85 \\
\hline 19 & VELISA RAYYA & 81 & 88 & 100 & 95 \\
\hline 20 & VELLCY VE L. & 75 & 84 & 98 & 90 \\
\hline 21 & ZAM ZAM Y. K. & 70 & 72 & 74 & 80 \\
\hline 22 & CHELSEA O. & 90 & 92 & 81 & 85 \\
\hline & Jumlah & 1554 & 1696 & 1870 & 1942 \\
\hline & Rata-rata & 70,6 & 77,1 & 85 & 88,3 \\
\hline & Jumlah Tuntas & 12 & 17 & 20 & 22 \\
\hline & Jumlah Belum Tuntas & 10 & 5 & 2 & 0 \\
\hline & Presentase Tuntas & $54,5 \%$ & $77,3 \%$ & $90,1 \%$ & $100 \%$ \\
\hline & Presentase Belum & $45,5 \%$ & $22,7 \%$ & $9,9 \%$ & $0 \%$ \\
& Tuntas & & & &
\end{tabular}

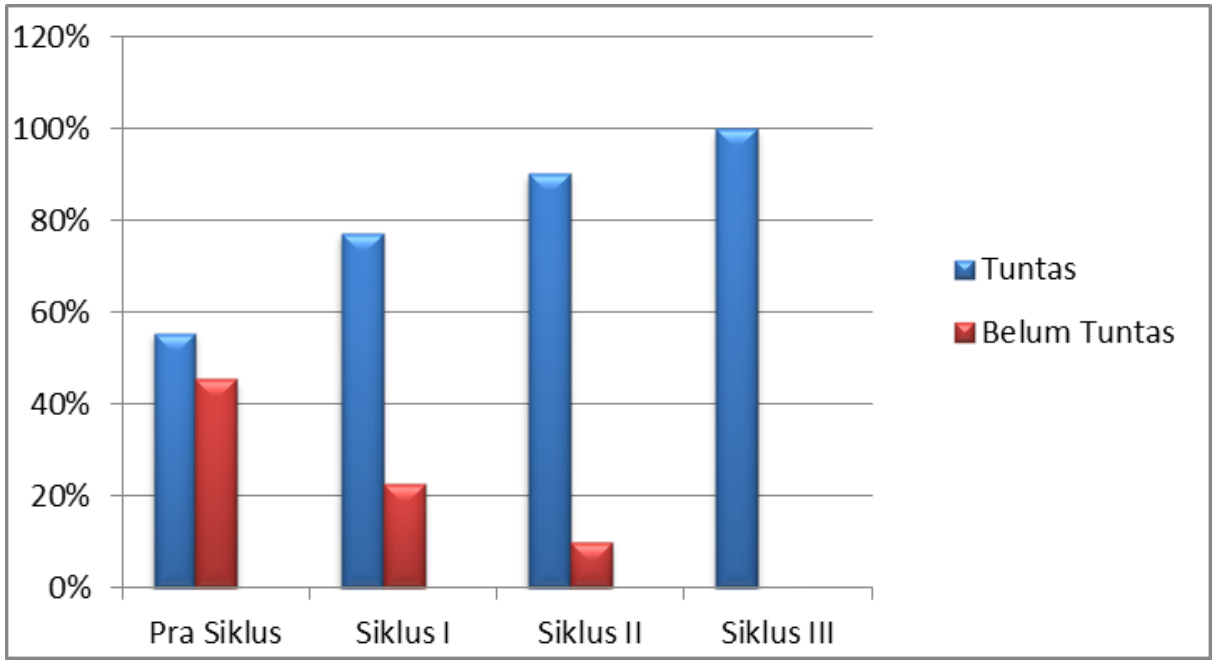

Gambar 1. Diagram Peningkatan Hasil Belajar Siswa

Tabel dan gambar di atas menunjukkan adanya peningkatan nilai ratarata dan ketuntasan belajar yang diperoleh siswa. Hasil belajar siswa diukur dengan teknik tes menggunakan instrumen evaluasi berupa soal pilihan ganda, isian singkat, dan uraian. Soal dibuat menggunakan google form karena kondisi sekolah berada pada zona merah sehingga pembelajaran dilakukan secara daring. Pengumpulan data hasil belajar peserta didik dilakukan setiap selesai pembelajaran. Instrumen soal sudah mengacu pada Higher Order Thinking Skills (HOTS), yaitu mengukur aspek kognitif yang terdiri dari menganalisis (C4), mengevaluasi (C5), dan mencipta (C6). 
Penggunaan media power point dalam pembelajaran tematik kelas III di SD Negeri Kedawung 02 dapat meningkatkan hasil belajar siswa secara signifikan. Pada hasil penilaian kondisi awal terdapat 10 dari 22 siswa yang belum mencapai KKM atau 45,5 \%. Setelah dilakukan tindakan pada siklus I terdapat peningkatan jumlah siswa tuntas belajar, yaitu 17 dari 22 siswa atau 77,3\%. Pada siklus II juga terdapat peningkatan jumlah siswa tuntas belajar yaitu 20 dari 22 siswa atau $90.1 \%$. Pada siklus III hasil belajar siswa juga terus meningkat dan mencapai $100 \%$ siswa tuntas dengan KKM sekolah 70 sehingga pelaksanaan penelitian tindakan kelas dapat dihentikan.

Peningkatan hasil belajar tersebut sesuai dengan yang diungkapkan oleh Alamul Huda (2007:23), menyatakan bahwa Microsoft Powerpoint adalah salah satu bagian dari Microsoft Office yang ditujukan untuk membuat slide-slide presentasi yang menarik. Media powerpoint di setiap slidenya dapat menampilkan teks dan gambar bergerak dengan tata suara dan tata warna yang disesuaikan dengan penggunaannya sehingga dapat merangsang minat dan ketertarikan siswa terhadap suatu materi. Konsep pembelajaran yang dikemas dalam powerpoint dapat membantu siswa dalam memahami suatu konsep yang abstrak dan meningkatkan motivasi siswa serta membantu tercapainya tujuan suatu pembelajaran sehingga akan dapat meningkatkan hasil belajar siswa.

\section{SIMPULAN}

Berdasarkan hasil analisis data dapat ditarik kesimpulan sebagai berikut : 1) Pembelajaran menggunakan media powerpoint dapat meningkatkan hasil belajar siswa kelas III SD Negeri Kedawung 02. Hal tersebut dibuktikan dari nilai rata-rata yang mencapai 88,3 dengan ketuntasan $100 \%$. 2) Pembelajaran melalui penerapan media pembelajaran power point dapat membangkitkan semangat dan keaktifan siswa dalam kegiatan pembelajaran, sehingga hasil belajar dapat meningkat.

\section{DAFTAR PUSTAKA}

Agus, Suprijono. (2012). Metode dan Model-Model Mengajar. Bandung : Alfabeta.

Alamul Huda. (2007). Panduan Praktis Microsoft Powerpoint 2007. Surabaya: Penerbit Indah

Arikunto, S. (2013). Prosedur Penelitian. Jakarta: PT Rineka Cipta.

Arikunto, S., Suhardjono., \& Supardi (2008). Penelitian Tindakan Kelas. Jakarta: PT Bumi Aksara.

Ashar Arsyad. (2002). Media Pembelajaran. Jakarta : PT. Raja Grafindo Persada

Daryanto. (2010) . Media Pembelajaran Peranannya sangat penting dalam Mencapai Tujuan Pembelajaran. Yogyakarta: Gava Media

Depdiknas. 2003. Undang-Undang No. 20 tahun 2003. Jakarta: Departemen Pendidikan

Majid. (2004). Pembelajaran Tematik terpadu. Bandung: Remaja Rosda Karya.

Muslich, M. (2011). Melaksanakan PTK itu mudah. Jakarta: Bumi Aksara.

Nana Sudjana. 2005. Penilaian Hasil Proses Belajar Mengajar. Bandung : Rosdakarya

Nana Sudjana dan Ahmad Rivai. (2009). Media Pengajaran. Bandung: Sinar Baru Algensindo.

Oemar Hamalik. (2001). Kurikulum dan Pembelajaran. Jakarta: Bumi Aksara.

. Proses Belajar Mengajar. Jakarta : Bumi Aksara

Purwanto. 2008. Evaluasi Hasil Belajar. Surakarta : Pustaka Pelajar

Riski Ilham (2004). Belajar Sendiri Langsung Praktek Microsoft Powerpoint 2002. Surabaya: Indah 
Rusman. 2011. Model-Model Pembelajaran Mengembangkan Profesionalisme Guru. Jakarta: Rajawali Pers

Alfabeta.

(2012). Belajar dan Pembelajaran Berbasis Komputer. Bandung: 